$5-6-1998$

\title{
Pollard Case Is One for the Legal Books
}

Kenneth Lasson

University of Baltimore School of Law, klasson@ubalt.edu

Follow this and additional works at: http://scholarworks.law.ubalt.edu/all_fac

Part of the International Law Commons, Military, War, and Peace Commons, and the National Security Law Commons

\section{Recommended Citation}

Pollard Case Is One for the Legal Books, The Baltimore Sun, May 6, 1998

This Editorial is brought to you for free and open access by the Faculty Scholarship at ScholarWorks@University of Baltimore School of Law. It has been accepted for inclusion in All Faculty Scholarship by an authorized administrator of ScholarWorks@University of Baltimore School of Law. For more information, please contact snolan@ubalt.edu. 


\section{Related Articles}

Caviar importer fined $\$ 10$ million

February 21, 2001

Two get prison terms for bank robberies

June 2, 2007

Man's drug conviction draws 12-year term

January 19, 2008

City man gets 4-plus years for child porn

January 20, 2007

City man pleads guilty in firebombing scheme June 16, 2006

\section{Find More Stories About}

\section{Judge}

Sentence

Plea Agreement

Dissent

\section{Pollard case is one for the legal books}

May 06, 1998 | By Kenneth Lasson

\begin{tabular}{lll} 
Recommend & $\sqrt{0}$ & \\
\hline Tweet & $\bullet \vdots$ & 0 \\
& $\bullet \vdots$ & $\mathbf{G + 1}$
\end{tabular}

JONATHAN Pollard, the former Navy intelligence analyst who was convicted of passing classified information to Israel, has been behind bars for more than 12 years now. His life sentence -- by far the harshest ever meted out for a similar offense -- continues to make "equal justice under law" seem like little more than a palsied proverb.

Pollard's actions were clearly misguided and rightly punishable, but should he languish for life in prison while others obviously more perfidious have been set free? Americans who expect fairness in their judicial system should be sorely disillusioned at how grossly disproportionate Pollard's treatment has been, not to mention how duplicitous his prosecution.

Consider these facts: Shortly after he was caught, the government entered into a standard plea agreement, seeking leniency in exchange for information. Once Pollard had fully cooperated, the prosecutor promptly reneged on his promise. The lower court judge not only ignored the plea agreement but also considered a secret memorandum from then-Secretary of Defense Caspar Weinberger that offered speculative evidence -- none of which Pollard or his lawyers have had a chance to challenge. Mr. Weinberger conjured up specters of unprecedented treachery. The judge sentenced Pollard to life in prison, and the prosecutor who agreed not to seek a harsh penalty recommended that he never be paroled.

And indeed he hasn't been

The injustice was devastatingly articulated by Judge Steven Williams in Pollard's failed 1992 appeal to the Washington, D.C., Circuit Court. In a long, analytical and sharply worded dissent (the two other appellate judges affirmed the conviction on narrow procedural grounds), Judge Williams called "the government's breach of the plea agreement a fundamental miscarriage of justice."

Even in the unforgiving world of international espionage, Pollard's punishment should be considered excessive when compared with other cases.

Making a case

Here are some of the more recent ones:

From 1992 to 1994, U.S. Navy Lt. Commander Michael Schwartz delivered secret U.S. defense information to Saudi Arabia. Indicted for violating various federal statutes as well as the Uniform Code of Military Justice, Schwartz pleaded guilty. His punishment: an "other than honorable" discharge from the Navy. No fine, no prison and no comment. (In fact, the government has been remarkably mum about Schwartz. Neither the White House nor the Pentagon will comment on his case. Nor was any public protest ever lodged against the Saudis, as it was against the Israelis.

From 1994 to 1996, Harold Nicholson received some $\$ 300,000$ for selling secrets to Russia, and, in the process, blowing the covers of a number of U.S. agents abroad. Nicholson, the highest-ranking CIA officer ever caught spying against his own country, was sentenced to 23 years in prison. He was spared a life sentence after prosecutors said he had cooperated with them.

Just last month Peter Lee, a nuclear physicist who gave secret national defense information to Chinese scientists and then lied about it to U.S. investigators, was sentenced to one year in a halfway house and ordered to perform 3,000 hours of community service.

Over the years, the dozens of other Americans who have been convicted of the same crime as Pollard have been sentenced to an average of four years in prison.

All the more ironic are the mirror-image cases. In the past 10 years, Israel has caught at least two Americans and one Mossad agent spying for the United States. The Americans were quietly expelled; the Israeli was pardoned.

The actual damage done by Pollard appears paltry compared with that of others given lesser sentences. After 13 years, not one instance has surfaced (or been documented in the victim impact statement written by his prosecutors) of any real harm that Pollard caused.

Why are these cases different? Because, one might reasonably surmise, of the purposes being pursued.

Oil and politics

With the Saudis, it's clearly petro-politics. Oil among allies is a powerful balm for soothing slights that violates the rules of international espionage. With the Russians, it's probably self-interested revisionist propaganda: No longer do we need to fear what a few years ago was the evil empire.

No such face-saving gestures need be offered the Israelis, with whom a different dynamic may be at work: There is ample reason to believe that Mr. Weinberger and others exploited Pollard to put Israel in its place as a strategic but beholden ally, as well as to call into question the "dual loyalty" of American Jews. One need not sniff hard to smell antiSemitism in the U.S. intelligence community. 
For Pollard, 43, wasting away at the federal penitentiary in Butner, N.C., equal justice under law does not appear to apply -- nor does the damage done matter when there are greater political causes to pursue.

Kenneth Lasson is a law professor at the University of Baltimore. This article originally appeared in the National Law Journal.

Pub Date: 5/06/98

From the Web

Sponsored Links

Maryland: Drivers Are Stunned By This New Rule

Provide Savings Insurance Quotes

How Are Baltimore Homeowners Cutting Their Electricity Bills In Half? SolarForHomes

Do You Binge-Watch Documentaries? You'll Love This Website LA Times | Curiosity Stream

Pay Off Your House At A Furious Pace If You Owe Less Than $\$ 625 \mathrm{k}$ LowerMyBills

Why This Shirt Company Is Causing so Many Guys to Switch Proper Cloth

Ron Paul Issues Warning On Gold

Stansberry Research

10 Clothes Middle-Aged Women Should Avoid

Lifescript

See The Online Furniture Store That Has Retailers Worried Wayfair

by Taboola

MORE:

A tale of customer service, justice and currency as funny as a $\$ 2$ bill

Family's bad fortunes propelled

Thomas to better life

Why expansion tank is needed

'Blushing' ear is no cause for alarm

Minor's future arrives early Rookie didn't expect to make a start at third this season 